\title{
Fis \\ PERCEPTION OF DIRECT AND INDIRECT COMPENSATIONS FULFILLMENT ON HAZARDOUS WORK ENVIRONMENT: THE RELATIONSHIP WITH AGE, TENURE, EMPLOYEE'S RANK AND WORK STATUS
}

\author{
Setyabudi Indartono \\ Chun-Hsi Vivian Chen \\ Department of Business Administration \\ National Central University \\ No. 300, Jungda Rd, Jhongli City \\ Taoyuan, Taiwan 320, ROC \\ Email:964401605@cc.ncu.edu.tw \\ Email:cvchen@mgt.ncu.edu.tw
}

\begin{abstract}
This paper investigates how ages, tenure, employee's rank and work status related to perception of direct and indirect compensations fulfillment in a hazardous work environment. This study found that age, tenure, employee's rank and work status are positively related to perception of direct and indirect compensations fulfillment. Implication for research and practice are discussed.
\end{abstract}

Keywords: Demographic characteristics, direct and indirect compensations, Hazardous work environment

\section{INTRODUCTION}

Hazardous working environment was a place that has a high level of safety and security attentions (Ghosh, 2007). Safe and secure environment are situations which are free of biological, chemical, physical, radiological, and other hazardous materials and safe for working (Mclain, 1995). Unsafe environment makes working people uncomfortable (Kent, 2001; Martellini 2003; Ghosh, 2007) and changes the attitude and behavior (Dreher, 1982). It makes higher stress (Tytherleigh, 2005; Ghosh, 2007), unbalance life and decrease the physical health (Tytherleigh, 2005). It also affects the attitude such as performance (Kent, 2001; Martellini 2003; Ghosh, 2007), perceived organizational support (Shore, 2004), commitment (Iverson, 2000), and turnover (Herpen, 2005).
Previous study found that compensation or reward is one of the most effective employees retaining on work (Sullivan, 2001), i.e. compensate more to employees in mining industry (Montpellier, 2005). Compensation schemes provide automatic rewards and incentives according to the changes of the environment (Nalebuff, 1983). Therefore, compensation is an attractive motivator for people who work on hazardous environment (Mohebbi 2007, Herpen, 2005, Kent 2001). In the study of compensation, there are dynamic applications of compensation strategy to attract and retain employee who work in high risk firm such as this hazardous environment (Comm, 2003). In hazardous working environment, employees need more attentions and support by employers such as more rewards and compensation than the 
compensation than the low risk firm (Kent 2001). And also hazardous environment is particularly well-suited for examination of different methods of payment (Brown, 1990; White, 2006).

The relations between employee characteristics and compensation in previous studies indicated that employee on different age has a different perception of compensation (Debra, 2007, Hertzberg et.al 1957, Montpellier, 2005) base on their maturity, family needs and expectation. Higher involvement and maturity for longer tenured employees indicate that they perceive more favorable view on compensation (Rhoades, 2002). And different attitude of employee rank perceive different on reward (Eisenberger, 1990).

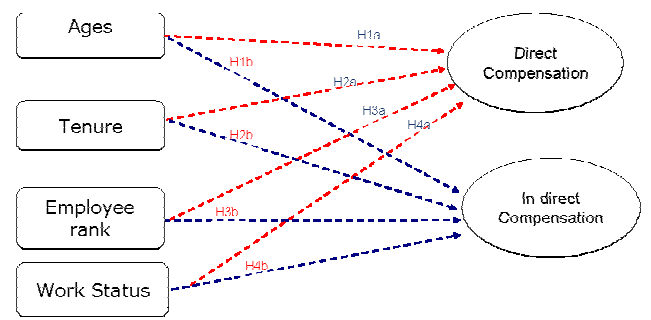

Figure 1. Research model

Base on the previous explanation of rationale problems, the objective of this study is to investigate relation between compensation and employee characteristics (Sullivan, 2001) such as ages, tenure, employee's rank and work status (Kirjonen, 1996). The setting of the study is mining operation as a hazardous situation.

\section{LITERATURE REVIEW Compensation}

Compensation is defined as a wages and benefit given in exchange for effort or work (Milkovich, 1999). It has a lot of influence on employee working behavior and also affect the work performance (Kent 2001). Compensation consisted of direct compensation and indirect compensation
(Mccaffery, 2005). Both have different behavior affects. As an example, payment as direct compensation will affect employee self-esteem (Gardner, 2004), work satisfaction, turnover intent (Herpen, 2005) and other behavioral and attitudinal of employees (William 1996, McClausland 2005, Iverson 2000, Groves 1973, Martellini 2003, Balkin, 1990, Pearce 1985, Shore, 2004). Benefit and service as indirect compensation will affect behavior on satisfaction (Spitzer, 1996), stress (Kirjonen, 1996), and also affect on the increase of participation and contribution (Edwards, 1983, Eisenberger, 1990, Mccaffery, 2005).

Because the hazardous work environment related to the uncomfortable situation and effect on behavior (Iverson, 2000), the employer expect to pay greater proportion of variable rewards (Kent 2001). Previous study found that compensations had positive association with reduced organizational-level injuries (Lauver, 2007) and other suspect behaviors. Thus it was suggested that parts of the solution were increase indirect compensation, i.e. the benefit and or direct compensation, i.e. wages (Sullivan, 2001).

\section{Theoretical background and hypotheses}

According to previous studies (Epstein, 2006, Moyes, 2006, Martin 2006, Montpellier, 2005, Pravin 2004, Sarker, 2003, Sullivan, 2001, Mc Donald, 2000, Kirjonen, 1996, Rousseau, 1995, Gibson, 1970), stress symptoms were indicated by different behavior in ages, tenure, employee rank and work status. Demographic characteristics of employees are often used as research moderator variables. For example, longer tenure employees who are dissatisfied within organization may different with the shorter one (Rhoades, 2002). Permanent employees has high favorable perceive better than contract employee (Lynch, 1999). Hence, hypotheses were developed with 
approaches of perceive indicators for each employee characteristics (Sullivan, 2001).

The phenomena of employee's age on work changes as far as employee growing mature. Young age employee has higher ambitions and expectations of the availability of the job rewards than the old one (Debra, 2007). Moral indication tends to be higher among young workers (Hertzberg et. all., 1957), but the conflicts experiences, due to work/family life changes better as employees grow older. Thus, the trend seems to move downward during the first few years of employment resembling a "U" shape in pattern (Hertzberg et. all., 1957). Old-age employee's payment was increased by employer in mining industry (Montpellier, 2005). Supported by the indications of different ambitions, expectations, moral and pay applications on work of age, therefore to get better understanding of relationship between ages and perceived of compensation fulfillment, this study predicts that age is positively related to employee's perception of compensation fulfillment (H1):

$\mathrm{H1a}$ : age is positively related to employee's perception of direct compensation fulfillment

$\mathrm{H} 1 \mathrm{~b}$ : age is positively related to employee's perception of indirect compensation fulfillment

Employee's tenure has several different behavioral indications on work such as involvement and maturity. Tenure with the service of 5 to 12 years are highly involved in their work as compared to the employees who have service of more than 12 years and the employees who have service less than 5 years (Pravin 2004). Longer tenured employees have more favorable view of various aspects of their treatment by the organization (Rhoades, 2002). In hazardous working environment, longer tenure has more identity and mature well to their environmental work (Ghost, 2007), that make more wisdom perceived their organizational support. Therefore to make conclusions from the indications, this research derives a prediction that tenure is positively related to employee's perception of compensation fulfillment $(\mathrm{H} 2)$ :

$\mathrm{H} 2 \mathrm{a}$ : Tenure is positively related to employee's perception of direct compensation fulfillment

$\mathrm{H} 2 \mathrm{~b}$ : Tenure is positively related to employee's perception of indirect compensation fulfillment

A high rank employee was reported to have more positive attitudes during changes than the low rank one (Martin 2006). High employee rank also had lower level of stress relating to work-life balance, overload and job overall, and lower levels of physical ill-health (Tytherleigh 2005). In the case of hazardous working environment that related to the impact of conditions of work, overload and stress, family isolation, injuries opportunity and negative affectivity on life satisfaction (Iverson, 2000), the high employee rank that have more positive attitude would perceive as well as high reward (Eisenberger, 1990). Therefore, if it is extended to the previous study, this study predicts that employee rank is positively related to employee's perception of direct compensation fulfillment $(\mathrm{H} 3)$ :

$\mathrm{H} 3 \mathrm{a}$ : Employee rank is positively related to employee's perception of direct compensation fulfillment

$\mathrm{H} 3 \mathrm{~b}$ : Employee rank is positively related to employee's perception of indirect compensation fulfillment

The proportion of the workforce on temporary contracts of employment is increasing, as organizations use contract employee as a flexible resource (Rousseau, 1995). The contract employees have more working involvement as compared to permanent ones (Pravin, 2004). But permanent 
staff has more relational contract and the commitment of organizational and job satisfaction was higher than the temporary one (Mc Donald, 2000). Therefore, this study derives prediction that, work status is positively related to employee's perception of direct compensation fulfillment (H5):

$\mathrm{H} 4 \mathrm{a}$ : Work status is positively related to employee's perception of direct compensation fulfillment

$\mathrm{H} 4 \mathrm{~b}$ : Work status is positively related to employee's perception of in direct compensation fulfillment

Based on Sarker (2003) study, it was written that tenure significantly modified by ages, was used in as scenario to increase the perceived of fulfillment. This study used three equation approach based on baron and Kenny (1986). Thus, we observe the influence of the tenure change effected by modifications of ages.

\section{METHODS}

\section{Participant and Setting}

The samples of this study consist of 107 employees from mining industry in Indonesia. Questionnaires were distributed to 250 employees and 107 were collected, for two months collection process. The sample populations for the study were collected from Indonesia copper and gold mining company. This site is located in 3800 to 4200 meters above sea level, highest mountain in Indonesia, Jaya Wijaya, Papua Island, with average temperature of 12 degree of Celsius. Researcher collected all of data questionnaires in all service area of surface and underground mining area, maintenance and service department, marine and transportation service, finance, safety and human resources services, based on safety training list in safety training department at several levels and grades. The study limited respondents at age limitation of up to 30 years old, whereas the above 30 years old were placed in the older group (Moyes, 2006). These samples consist of $93 \%$ more than 35 years old employees, with mean of 46.92 years old, $71 \%$ longer tenure employees, with mean of 14.77 years service, $76 \%$ high level employee and $66.4 \%$ permanent employee status.

\section{Measure}

Compensation questionnaire was developed based on total compensation form (Milcovich 1999), it was contained of two dimensions of compensation, direct and indirect compensation. Validity test (Pearson product moment correlation) and reliability (Cronbach alpha) were conducted twice. First test were 53 questionnaires that was returned from 80 questionnaires that was distributed at a general hospital in Jogjakarta, and then on site test were 93 questionnaires returned from 200 questionnaires distributed of Freeport company job site Papua Indonesia. Fifty one items of all attributes were corrected to 28 valid items by deleting 14 direct compensation items and 9 indirect compensation items, in the first test. Then, 28 items were corrected to 13 valid items by deleting 7 direct compensation items, and 8 indirect compensation items in the final test.

\section{Direct compensation fulfillment}

Five item questions were of perceived direct compensation fulfillment i.e. Fulfillment of base wages, base wage adjustment, cost of living allowance, long-term incentive and short term bonus. Total of 5items used Likert 5 point scale ranging from strongly disagree (1) to strongly agree (5). The perceived of direct compensation fulfillment scale reliability, Cronbach's alfa, was 0.635 .

\section{In Direct compensation fulfillment}

Eight items questions were of perceived indirect compensation fulfillment, i.e. 
fulfillment of safety allowance, healthy allowance, work's tools availability, end-year gift, breaking time on work, vacation time, vacation allowance, and work room availability. Total of 8-items used Likert 5 point scale ranging from strongly disagree (1) to strongly agree (5). The perceived of indirect compensation fulfillment scale reliability, Cronbach's alfa, was 0.756 .

\section{Demographic characteristics}

Employee characteristics of respondents were contained of tenure: age (Moyes, 2006), tenure (Sarker, 2003), Employee rank (Rousseau 1995; Martin, 2006; Tytherleigh, 2005) and work status (Mc Donald, 2000; Pravin 2004; Epstein, 2006).

\section{Analysis}

The correlation was used to test relationship between employee characteristics and each of perceived compensation fulfillments. T-test and Analysis of Variance ANOVA were used to test the hypothesized difference of perceive compensation fulfillment between each pair of employee demographic characteristics, such as pair of ages, pair of employee rank, pair of work status and type of tenure. The test of increasing scenario of perceives fulfillment was done by regression.

We observe the influence of the change of tenure effect by modification of ages. Age will be as a mediator on relationship between Tenure and perceived of fulfillment. The procedure was regressed the mediator on the independent variable, dependent variable on the independent variable, and finally dependent variable simultaneously on both the independent variable and on the mediator. According to Baron and Kenny (1986), mediation is demon- strated if the independent variable affects the mediator in their first equation and the dependent variable in their second equation, the mediator affects the dependent variable in their third equation and the effect of the independent on the dependent variable is less in the third than the second equation.

\section{RESULT}

The correlation between employee characteristics and perceive of compensation fulfillment items

Table 1 contains of the descriptive statistics and a correlation matrix for all variables in this study. Table 1 presents the correlation between employee characteristics and perceive of compensation fulfillment items. Ages has positive correlation to compensation $(\mathrm{p}<.01)$ both in direct $(\mathrm{p}<.01)$ and indirect compensation $(\mathrm{p}<.01)$, thus supporting hypothesis 1 . Tenure has a positive correlation to compensation $(p<.01)$ both in direct $(\mathrm{p}<.05)$ and indirect compensation ( $\mathrm{p}<.01)$, thus supporting hypothesis 2 . Employee's rank has a positive correlation to compensation $(\mathrm{p}<.01)$ both in direct $(p<.01)$ and indirect compensation $(p<.05)$, thus supporting hypothesis 3 . Work status has a positive correlation to compensation $(p<.01)$ both in direct $(p<.01)$ and indirect compensation $(\mathrm{p}<.05)$, thus supporting hypothesis 4. In sum all of hypotheses were supported but in a varying significant values.

The study also found strong correlation between employee characteristics and items. Age has strong correlation with compensation both in direct and indirect compensation, but tenure and employee's rank has strong correlation with direct compensation. 
Table 1. Means, Standard Deviation and Correlation Among Demographic Characteristics and Items

\begin{tabular}{lccccccccc}
\hline Perceive of fulfillment & Mean & SD & $\mathbf{1}$ & $\mathbf{2}$ & $\mathbf{3}$ & $\mathbf{4}$ & $\mathbf{5}$ & $\mathbf{6}$ & $\mathbf{7}$ \\
\hline Direct Compensation & 3.51 & .48 & 1 & & & & & & \\
Indirect Compensation & 3.73 & .53 & $.699^{* *}$ & 1 & & & & & \\
Total Compensation & 3.65 & .47 & $.870^{* *}$ & $.961^{* *}$ & 1 & & & & \\
\hline Ages & 45.4 & 7.00 & $\mathbf{. 6 7 7 ^ { * * }}$ & $\mathbf{. 5 5 2 ^ { * * }}$ & $\mathbf{. 6 4 4 ^ { * * }}$ & 1 & & \\
Tenure & 10.5 & 5.05 & $\mathbf{. 6 2 6 ^ { * * }}$ & $.234^{*}$ & $.263^{* *}$ & $.488^{* *}$ & 1 & & \\
Employee Rank & 1.29 & .456 & $\mathbf{. 5 0 0 ^ { * * }}$ & $.225^{*}$ & $.394^{* *}$ & $.182^{*}$ & -.083 & 1 & \\
Work status & 1.35 & .478 & $.392^{* *}$ & $.238^{*}$ & $.316^{* *}$ & $.207^{*}$ & .121 & $.315^{* *}$ & 1 \\
\hline
\end{tabular}

** Correlation is significant at the 0.01 level (2-tailed).

* Correlation is significant at the 0.05 level (2-tailed).

Employee rank (1= non-staff), work status (1=permanent)

Different perceived of compensation fulfillment on each pair of employee demographic characteristics

Table 2a. Descriptive statistics and t-test table among demographics characteristics

\begin{tabular}{|c|c|c|c|c|c|c|c|c|c|c|}
\hline & & \multirow[t]{2}{*}{ Percent } & \multirow[t]{2}{*}{ Mean } & \multirow[t]{2}{*}{ SD } & \multicolumn{2}{|c|}{$\begin{array}{c}\text { Direct } \\
\text { Compensation }\end{array}$} & \multicolumn{2}{|c|}{$\begin{array}{c}\text { In Direct } \\
\text { Compensation }\end{array}$} & \multicolumn{2}{|c|}{$\begin{array}{c}\text { Total } \\
\text { Compensation }\end{array}$} \\
\hline & & & & & Mean & $\mathbf{t}_{\text {value }}$ & Mean & $t_{\text {value }}$ & Mean & $t_{\text {value }}$ \\
\hline Ages & 107 & & 1.93 & 0.26 & & $10.62 * *$ & & $3.45^{* *}$ & & $5.35^{* *}$ \\
\hline Younger & 8 & $7 \%$ & & & 2.38 & & 2.71 & & 2.58 & \\
\hline Older & 99 & $93 \%$ & & & 3.60 & & 3.81 & & 3.73 & \\
\hline $\begin{array}{l}\text { Employee } \\
\text { rank }\end{array}$ & 107 & & 1.29 & 0.46 & & $5.92 * *$ & & $2.65^{* *}$ & & $3.82 * *$ \\
\hline Non Staff & 31 & $29 \%$ & & & 3.36 & & 3.66 & & 3.54 & \\
\hline Staff & 76 & $71 \%$ & & & 3.88 & & 3.92 & & 3.90 & \\
\hline Work Status & 107 & & 1.35 & 0.48 & & $-4.37 * *$ & & $-2.51 *$ & & $-3.42 * *$ \\
\hline Permanent & 71 & $66.4 \%$ & & & 3.37 & & 3.64 & & 3.55 & \\
\hline Contract & 36 & $33.6 \%$ & & & 3.77 & & 3.90 & & 3.82 & \\
\hline
\end{tabular}

* Significant at the 0.05 level $(\mathrm{t}$ table $=1.96)$

** Significant at the 0.01 level $(\mathrm{t}$ table $=2.61)$

Table 2b. Descriptive statistics and one way Anova of Tenure

\begin{tabular}{|c|c|c|c|c|c|c|c|c|c|c|}
\hline & & \multirow[t]{2}{*}{$\begin{array}{l}\text { Per- } \\
\text { cent }\end{array}$} & \multirow[t]{2}{*}{ Mean } & \multirow[t]{2}{*}{ SD } & \multicolumn{2}{|c|}{$\begin{array}{l}\text { Direct Compen- } \\
\text { sation }\end{array}$} & \multicolumn{2}{|c|}{$\begin{array}{c}\text { In Direct Com- } \\
\text { pensation }\end{array}$} & \multicolumn{2}{|c|}{$\begin{array}{c}\text { Total Compen- } \\
\text { sation }\end{array}$} \\
\hline & & & & & Mean & $\mathbf{F}_{\text {value }}$ & Mean & $\mathbf{F}_{\text {value }}$ & Mean & $\mathbf{F}_{\text {value }}$ \\
\hline Tenure & 107 & & 2.13 & 0.515 & & $\begin{array}{l}47.30^{*} \\
*\end{array}$ & & $18.45^{*}$ & & $32.5 * *$ \\
\hline$<5$ years & 8 & $7.5 \%$ & & & 2.40 & & 2.80 & & 2.64 & \\
\hline $5-12$ years & 77 & $72.0 \%$ & & & 3.65 & & 3.83 & & 3.76 & \\
\hline$>12$ years & 22 & $20.5 \%$ & & & 3.42 & & 3.70 & & 3.59 & \\
\hline
\end{tabular}

* Significant at the 0.05 level (F table: 3.94$)$

** Significant at the 0.01 level (F table: 6.90) 
The hypotheses of this study suggested that each pair of employee characteristics would differ on certain perceived of compensation fulfillments. Hyphoteses-1 predicted that age is positively related to employee's perception of compensation fulfillment. As shown in table 2a, an elder employee has higher perceived of direct compensation fulfillments than the younger ones, $\mathrm{t}(107)=10.62, \mathrm{p}<.01(\mathrm{H} 1 \mathrm{a})$, perceived of indirect compensation fulfillments $t(107)=3.45, p<.01(\mathrm{H} 1 \mathrm{~b})$, perceived of total compensation fulfillments $\mathrm{t}(107)=5.35$, $\mathrm{p}<.01$. Thus hypothesis- 1 is accepted. Hyphoteses- 2 predicted that tenure is positively related to employee's perception of compensation fulfillment. As shown in table $2 b$, a middle tenure employee has higher perceived of direct compensation fulfillments than the both of lower and higher ones, $\mathrm{F}(107)=47.30, \mathrm{p}<.01(\mathrm{H} 2 \mathrm{a})$, perceived of indirect compensation fulfillments $\mathrm{t}(107)=18.45, \quad \mathrm{p}<.01(\mathrm{H} 2 \mathrm{~b}), \quad$ perceived of total compensation fulfillments $\mathrm{t}(107)=32.5$, $\mathrm{p}<.05$. Thus hypothesis- 2 is accepted. Hyphoteses-3 predicted that Employee rank is positively related to an employee's perception of compensation fulfillment. As shown in table 2a, a high level employee has higher perceived of direct compensation fulfillments than the lower ones, $\mathrm{t}(107)=5.92$, $\mathrm{p}<.05(\mathrm{H} 3 \mathrm{a})$, perceived of indirect compensation fulfillments $\mathrm{t}(107)=2.65, \quad \mathrm{p}<.05$ $(\mathrm{H} 3 \mathrm{~b})$, perceived of total compensation fulfillments $\mathrm{t}(107)=3.82, \mathrm{p}<.05$. Thus hypothesis-3 is accepted. Finally, hyphoteses-4 predicted that work status is positively related to employee's perception of compensation fulfillment. As shown in table $2 \mathrm{a}$, a contract employee has higher perceived of direct compensation fulfillments than the perma- nent ones, $\mathrm{t}(107)=-4.37, \mathrm{p}<.05(\mathrm{H} 4 \mathrm{a})$, perceived of indirect compensation fulfillments $t(107)=-2.51, p<.01$, perceived of total compensation fulfillments $\mathrm{t}(107)=-3.42, \mathrm{p}<.05$ (H4b). Thus hypothesis-4 is accepted.

\section{A scenario development to increase the perceive fulfillment by mediating effect of Employee Demographic Characteristics $(\beta)$ on Perceived of compensation fulfill- ment}

We observe modification effect of ages on tenure by mediating effect of Employee Demographic Characteristics $(\beta)$ on Perceived of compensation fulfillment. Table-3a to $3 \mathrm{~d}$ showed that Ages have full mediated the relationship between Tenure and perceived of direct compensation fulfillment $\left(\beta=.262^{* *} ; \beta^{\prime}=.-.09\right)$, indirect compensation fulfillment $\left(\beta=.234^{* *} ; \beta\right.$, $\left.\beta^{\prime}=046\right)$ and total compensation fulfillment $\left(\beta=.263^{* *} ; \beta^{\prime}=-.068\right)$ and surprisingly, age also full mediated the relationship between work status and perceived of indirect compensation fulfillment $(\beta=.239 * * ; \beta$ ' $=.130)$.

Regression among Demographic characteristics in table-4 showed the variety effect of Employee characteristics to all of perceived fulfillment. Age influences to all of compensation items. Tenure influences to Base wage, Base Wage Adjustment, Short term bonus, Safety pay, and Vacation pay. Level of employee influences to Base wage, Base Wage Adjustment, Short term bonus, healthy pay, Safety pay, break time on work, and Vacation. And also status employee influences to Base wage, Base Wage Adjustment, Short term bonus, Safety pay, and Healthy pay, Break time on work, Vacation, and Vacation pay. 
Table 3a. Mediated regression analysis for Tenure

\begin{tabular}{lllcrrr}
\hline $\begin{array}{c}\text { Equa- } \\
\text { tion }\end{array}$ & $\begin{array}{c}\text { Independent } \\
\text { Variable }\end{array}$ & \multicolumn{1}{c}{ Dependent Variable } & $\begin{array}{c}\boldsymbol{\beta} \text { for inde- } \\
\text { pendent } \\
\text { variable }\end{array}$ & F & $\mathbf{R}^{\mathbf{2}}$ \\
\hline 1 & Tenure & Age & $.488 * *$ & $32.825 * *$ & .231 \\
2 & Tenure & Perceived Direct Compensation Fulfillment & $.262 * *$ & $7.729 * *$ & .060 \\
3 & Tenure & Perceived Direct Compensation Fulfillment & -.090 & $45.017 *$ & .454 \\
& Age & Perceived Direct Compensation Fulfillment & $.677 * *$ & $88.683 * *$ & .453 \\
\hline
\end{tabular}

** Significant at the 0.01 level

* Significant at the 0.05 level

Table 3b. Mediated regression analysis for Tenure

\begin{tabular}{lllcccc}
\hline $\begin{array}{c}\text { Equa- } \\
\text { tion }\end{array}$ & $\begin{array}{c}\text { Independent } \\
\text { Variable }\end{array}$ & \multicolumn{1}{c}{ Dependent Variable } & $\begin{array}{c}\boldsymbol{\beta} \text { for inde- } \\
\text { pendent } \\
\text { variable }\end{array}$ & F & & $\mathbf{R}^{2}$ \\
\hline 1 & Tenure & Age & $.488 * *$ & 32.825 & $* *$ & .231 \\
2 & Tenure & Perceived in Direct Compensation Fulfillment & $.234 *$ & $6.068 *$ & .046 \\
3 & Tenure & Perceived in Direct Compensation Fulfillment & -.046 & 22.943 & $* *$ & .293 \\
& Age & Perceived in Direct Compensation Fulfillment & $.522 * *$ & 45.974 & $* *$ & .298 \\
\hline
\end{tabular}

** Significant at the 0.01 level

* Significant at the 0.05 level

Table 3c. Mediated regression analysis for Tenure

\begin{tabular}{lllcrcc}
\hline $\begin{array}{c}\text { Equa- } \\
\text { tion }\end{array}$ & $\begin{array}{c}\text { Independent } \\
\text { Variable }\end{array}$ & \multicolumn{1}{c}{ Dependent Variable } & $\begin{array}{c}\boldsymbol{\beta} \text { for inde- } \\
\text { pendent } \\
\text { variable }\end{array}$ & F & $\mathbf{R}^{2}$ \\
\hline 1 & Tenure & Age & $.488 * *$ & 32.825 & $* *$ & .231 \\
2 & Tenure & Perceived total Direct Compensation Fulfillment & $.263 * *$ & $7.773 * *$ & .060 \\
3 & Tenure & Perceived total Direct Compensation Fulfillment & .068 & 37.354 & $* *$ & .407 \\
& Age & Perceived total Direct Compensation Fulfillment & $.644 * *$ & $74.347 * *$ & .409 \\
\hline
\end{tabular}

** Significant at the 0.01 level

Table 3d. Mediated regression analysis for Status

\begin{tabular}{lllllll}
\hline Equation & $\begin{array}{c}\text { Independent } \\
\text { Variable }\end{array}$ & \multicolumn{1}{c}{ Dependent Variable } & $\begin{array}{c}\boldsymbol{\beta} \text { for inde- } \\
\text { pendent } \\
\text { variable }\end{array}$ & F & $\mathbf{R}^{2}$ \\
\hline 1 & Status & Age & $.207 *$ & $4.683 * *$ & .034 \\
2 & Status & Perceived in Direct Compensation Fulfillment & $.239 *$ & $6.313 * *$ & .048 \\
3 & Status & Perceived in Direct Compensation Fulfillment & .130 & $24.538 * *$ & .308 \\
& Age & Perceived in Direct Compensation Fulfillment & $.522 * *$ & $45.974 * *$ & .298 \\
\hline
\end{tabular}

** Significant at the 0.01 level

* Significant at the 0.05 level 
Table 4. Regression among Demographic characteristics and compensation items

\begin{tabular}{|c|c|c|c|c|c|c|c|c|}
\hline \multirow[b]{2}{*}{ Base wage } & \multicolumn{2}{|c|}{ Ages } & \multicolumn{2}{|c|}{ Tenure } & \multicolumn{2}{|c|}{$\begin{array}{c}\text { Level of em- } \\
\text { ployee }\end{array}$} & \multicolumn{2}{|c|}{$\begin{array}{c}\text { Status of Em- } \\
\text { ployee }\end{array}$} \\
\hline & .357 & ** & .245 & $* *$ & .217 & $* *$ & .215 & $*$ \\
\hline Base Wage Adjustment & .495 & ** & .243 & ** & .293 & ** & .265 & $* *$ \\
\hline Cost of living allowance & .325 & $* *$ & .076 & & .151 & & .126 & \\
\hline Long term incentive & .211 & * & .193 & & .138 & & .180 & \\
\hline Short term bonus & .675 & * & .351 & $* *$ & .341 & $* *$ & .300 & $* *$ \\
\hline Safety pay & .495 & ** & .243 & $*$ & .293 & $* *$ & .265 & $* *$ \\
\hline Healthy pay & .382 & ** & .103 & & .217 & * & .216 & $*$ \\
\hline Work tools fulfillment & .330 & $* *$ & .141 & & .073 & & .163 & \\
\hline End year gift & 344 & $* *$ & .115 & & .114 & & .159 & \\
\hline Break time on work & 516 & $* *$ & .175 & & .309 & $* *$ & .361 & $* *$ \\
\hline Vacation & .576 & $* *$ & .300 & & .283 & $* *$ & .250 & $* *$ \\
\hline Vacation pay & .246 & $*$ & .025 & $* *$ & .171 & & .217 & * \\
\hline Work room availability & .322 & $* *$ & .174 & & .059 & & .032 & \\
\hline
\end{tabular}

* Significant at the 0.05 level

** Significant at the 0.01 level

\section{DISCUSSIONS AND CONCLUSIONS Discussions}

Related to these findings, the result of perceive value of each pair Employee characteristics, is consistent with the indications of previous researches. The older employees perceive compensation fulfillment more then the younger ones is in concordance with Moyes (2006) and Debra (2007). It could be explained with some reasons. For example as Debra (2006) finding that young ages have higher ambitions and more expectations for the availability of job rewards than the elder ones. This behavior will affect the level of perceive of fulfillment as well. Higher ambitions and expectations of compensation would exceed their expectations achievement. It cause their perceived of compensation was not fulfilled. Also employer increased their pay to old age employees in mining industries (Montpellier, 2005), increase their perceived of compensation fulfillment.

Middle tenure employees perceive compensation fulfillment is more then the highest and the lowest one, it is in agreement with Gibson, (1970), Silvestro (2002), Sarker (2003), Pravin (2004). It might be the longer tenured employees have a more favorable view of various aspects of their treatment by the organization (Rhoades, 2002) and they also have a more identity and more mature to their environmental work (Ghost, 2007), thus make them more wise perceiving these compensation fulfillments.

The high employee's rank are more perceive than the lower one, it is in agreement with the indications of study of $\mathrm{Mc}$ Donald (2000), Tytherleigh (2005), Martin (2006). It is because they have more positive attitudes than the lower ones (Eisenberger, 1990) then it make them wiser perceiving these compensation fulfillments.

This study also found that the low work status of employee perceived more than the higher ones. It was in accordance with the indications study of Mc Donald (2000) states of higher level of psychological contract, organizational commitment, 
and job satisfaction than permanent employees. And also similar with Pravin (2004) study which found that the work status of contract employees have more work involvement than the permanent ones. But it was difference with lynch (1999) study which found that permanent employee have higher favorable perceive than contract ones.

Variety of effect Employee characteristics to all of perceived fulfillment was explainable because of tenure with perceived of compensation fulfillment still could be improved with the increasing stability of psychological situations of ambitions and expectations of reward by increasing the age (Debra, 2007). It worked to perceive total compensation fulfillment, and both of direct and indirect ones. It also worked on work status but limited on perceived of in direct compensation fulfillment.

\section{Implication}

Generally this finding implied to ask several questions based on behavioral and attitudinal outcomes, such as how to increase productivity and performance (Gardner, 2004, Pearce, 1985, William 1996), employee self-esteem and participation (Edwards, 1983; Eisenberger, 1990; Mccaffery, 2005), satisfaction (Herpen, 2005, McClausland, 2005, Spitzer, 1996). And also ask questions of how to decrease turnover rate (McClausland, 2005), and stress (Kirjonen, 1996), increase and develop high trust and commitment, maintain retention, (Iverson, 2000), and increase the perceive of pay fairness (Shore, 2004).

Base on Milcovich (1999) study, compensation model concerns on strategic issued at the recent and future time. Compensation model become challenging on payment design based on job and organization design. This model becomes attractive on internal and external equity competitiveness. The findings of this study correlate with level and work status issues (Brown, 2006). High level employee face on complex issues, such as medical benefits, workers' compensation claims, payroll tax compliance, and unemployment insurance claims (Sammi, 1995). Low level employee face on legal issues and responsibilities of employer (Tauber, 2002), and face on conflict with the broader Labour Law directly (Lauffs 2005). High rank employee face on base salary, a minimum quota and bonuses through commissions, guiding on that may concentrate on maximizing their short-term revenue, firm's long-term advantage, measuring the performance, essential incentivebased plan, and management attention to ensure a competent and staff's trustworthy (Lee, 1989).

Result of this study indicated that compensation fulfillments are perceived differently by different ages, tenure, and level of employee. Compliance and claim within the organization, guided the employee to focus on their performance, competencies and trustworthy. All hypotheses of this study are supported. Those are any differences perceive on Employee characteristics through compensation both direct and in direct fulfillment. They give effects for the management to increase both internal and external equity, design of payments structure fairly and suitable with the general business strategic issues are faced (Milcovich, 1999). This research contributes to the application of payment or compensation development strategy, in internal and external equities perspectives (Milcovich, 1999), from conceptual and practical point of view (William 1996).

\section{Limitation and Future Research}

The study focus to differentiate perceive of direct and in direct fulfillment by employee characteristics. The real situation is not as simple as well. The situations may influence by a lot of moderations (time, 
work group setting and social setting) or by factor in person/perceivers (attitudes, motives, interests, experiences and expectations or behavior). They face with the hallo and or contras effect, group or organizational level moderator and intervention are given (Robbins 2006). The strategic level behind the compensation policies are effected by perceive of personal, i.e. job and organization design in order to pay design and the compensation goals both of internal and external equity (Milcovich 1999).

There were several future challenges for compensations study, such as changing of human resources reward paradigm from mechanical sources to human being, union relationship (Binotto, 2007), post employer pay (Aspinwall, 2007), pay tax (Segal, 2007), and multi employer pay (Blumenstein, 2007). Compensations influence to the achievement of human resources and organizational objectives increase, such as reinforce to overall corporate objectives to increase profitability, individual and team effort focus, and emphasize on shot-term and long term strategies (William 1996; milcovich 1999; P Robbin, 2006).

\section{REFERENCES}

Aspinwall, M. (2007), "Special Report for LTA Subcommittee Chairs on Recent Pension and Executive Compensation Legislation", The Cooperative Accountant, Vol. 60(Iss. 3).

Balkin, D.B. and Gomez-Mejia, L.R. (1990), "Matching compensation and organizational strategies", Strategic Management Journal, Vol. 11, pp. 153-69.

Baron RM; Kenny Da, (1986), “The moderator-mediator variable distinction in social psychological research: conceptual, strategic and statistical consideration", Journal of person- ality and Sozial psychology, 51, 1173-1182

Nalebuff, Barry J. and Joseph E. Stiglitz, (1983), "Prizes and Incentives: Towards a General Theory of Compensation and Competition", The Bell Journal of Economics, Vol. 14, No. 1, (Spring, 1983), pp. 21-43 Published by: The RAND Corporation

Binotto Jr., P. J., (2007), "A Management Strategy for Negotiating Changes in Health Care Benefits in Union Contracts" Compensation and Benefits Review, Vol. 39(Iss. 5): 5 pages

Blumenstein, D., Routh, Clifford H., (2007), "Multiemployer Defined Benefit Pension Plans: Why Their Future Looks Strong", Benefits \& Compensation Digest, Vol. 44(Iss. 11).

Brown, G., Xin, Wei, (2006), "Employment contracts in an M\&A situation, China Staff" Vol. 12(Iss. 1): 1 pg.

Brown, C., (1990), "Firms choice of method of pay", Industrial and Labour Relations Review, Vol. 43 No. 3, pp. 165-82.

Comm, C. L., Mathaisel, D, FX, (2003), “A case study of the implications of faculty workload and compensation for improving academic Quality", The International Journal of Educational Management; 17 pg. 200

Debra, Hunter, (2007), "Nonlinear Patterns of Job Satisfaction and Age Cohorts in an Industrial Environment", Journal of American Academy of Business, Cambridge. Hollywood: Sep 2007. Vol. 11, Iss. 2; pg. 231,8 pgs 
Dreher, G. F., Ash, Ronald A., Bretz, Robert D., (1988), "Benefit Coverage and Employee Cost: Critical Factors In Exp" Personnel Psychology Vol. 41(Iss. 2): 18 pgs.

Edwards, Christine; Heery, Edmund, (1983), "Formality and Informality in the Working of the National Coal Board's Incentive Scheme", Journal of industrial relation, 20, $\mathrm{p} / 25-45$

Eisenberger, Robert, Fasolo, Peter, DavisLaMastro, Valerie, (1990), "Perceived Organizational Support and Employee, Diligence, Commitment, and Innovation", Journal of Applied Psychology, Vol. 75, No. 1, 51-59

Epstein, G. S., Ward, Melanie E, (2006), "Perceived income, promotion and incentive effects" International Journal of Manpower, Vol. 27 (Iss. 2).

Gardner, D. G., Van Dyne, Linn, Pierce, Jon L, (2004), "The effects of pay level on organization-based self-esteem and performance: A field study", Journal of Occupational and Organizational Psychology, Vol 77.

Ghosh, A. K., A, Bhattacherjee, (2007), "Predictors of occupational injuries among coal miners: causal analysis, Mining Technology", Transactions of the Institute of Mining \& Metallurgy, Vol. 116(Issue 1): p16-24.

Gibson, J. L., Klein, Stuart M, (1970), "Employee attitudes as a function of age and tanure: A reconceptual", Academy of Management Journal, 13: pg. 411.
Groves, Theodore, (1973), "Incentive in team", Econometrica, Evaston, vol 41, Iss 4, pg 617, 15 pgs

Herpen, M. v., (2005), "The Effects of performance measurement and compensation on motivation: an empirical study", De Economist, Vol. 153, NO. 3.

Hertzberg, F. I., Mausner, B., Peterson, R. O. \& Campwell, D. R., (1957), "Job Attitudes: Review of Research and Opinion", Psychological Service, Pittsburgh.

Iverson, R. D., Maguire, Catherine, (2000), "The relationship between job and life satisfaction: Evidence from a remote mining community", $\mathrm{Hu}$ man Relations, Vol. 53 (Issue 6): $33 \mathrm{p}$.

Kent, P., Siu, Michael, Walker, Julie, (2001), "The structure of middle management remuneration packages: An application to Australian mine managers", Australian Journal of Management, Vol. 26(Iss. 2): 18 pgs.

Kirjonen, J., Hänninen, Vilma, (1996), "Getting a Better Job: Antecedents and Effects", Human Relations, Vol. 39 (Issue 6): 14p.

Lauffs, A., Wilson, Jeffrey, (2005), "A bid for more workable law Labour regulation is being rethought", $\mathrm{Fi}$ nancial Times. London (UK): Oct 5, 2005.

Lauver, K. J. L., (2007), "Human Resource Safety Practices and Employee Injuries", Journal of Managerial Issues, Vol. 19(Iss. 3): 18 pgs.

Lee, J. Y., Royal, Michael A., (1989), "Deciding upon a Professional Compensation Plan", The National Pub- 
lic Accountant, Vol. 34(Iss. 2): 7 pgs

Lynch D, Patrick, Eisenberger, Robert, Armeli, Stephen, (1999), "Perceived Organizational Support: Inferior vesus superior performance by wary employees", Journal of Applied Psychology, vol. 84, No. 4, P. 467-483

Martellini, lionel; amenc, noel; vaissie, Mathieu, (2003), "Benefit and risk of alternative investment strategies, Journal of asset Management, 4,3, pg 96

Martin, A. J., Jones,Elizabeth S, Callan Victor J., (2006), "Status differences in employee adjustment during organizational change", Journal of Managerial Psychology Vol. 21(1): 18.

Mccaffery, R. M., (2005), "Benefits communication" Blackwell Encyclopedic Dictionary of Human Resource Management.

McCausland, W. D., Pouliakas K., Theodossiou I., (2005), "Some are punished and some are rewarded: A study of the impact of performance pay on job satisfaction", International Journal of Manpower Vol. 26(Iss. 7/8): 26 pgs.

McDonald, D., J, Peter, J, Makin, (2000), "The psychological contract, organizational commitment and job satisfaction of temporary staff" Leadership \& Organization Development Journal Vol. 21(Iss. 1/2).

Mclain, (1995), "Responses to Health and Safety Risk in the Work Environment", The Academy of Management Journal, Vol. 38, No. 6, pp. 1726-1743
Milcovich, G. T., Newman, Jerry M., assistant, (1999), "Compensation", Irwin Mcgraw Hill.

Mohebbi Ash; Tarca, Ann, Woodliff, David , (2007), "Managerial incentives and the treatment of pre-production expenditure in the mining industry", International Journal of Business Studies, Vol. 15, No. 1, pages 127 of 152

Montpellier, R., (2005), "Grey matters" CIM Buletin Vol. 98(Iss 1090): 1 pg.

Moyes, G. D., Williams, Patricia A., Koch,Bruce, (2006), "The effects of age and gender upon the perceptions of accounting professionals concerning their job satisfaction and work-related attributes" Managerial Auditing Journal Vol. 21(Iss. 5).

Pearce, J. L., Stevenson, William B., Perry, James L., (1985), "Managerial compensation based on organizational performance: A time series analysis an effect of merit pay", Academy of Management Journal, 28.

Pravin, G Deosthalee, (2004), "Relationship of work involvement with size of company, nature of appointment, and length of service of employees", Pakistan Journal of Psychological Research, Islamabad: Summer 2004. Vol. 19, Iss. 1/2; pg. 15, 9 pgs

Rhoades, L., Eisenberger, Robert, (2002), "POS a review of literature" Journal of Applied Psychology, Vol. 87. 
Robin, S. P., A judge, timothy, (2006), “Organizational behavior", Prentice hall.

Rousseau, D.M., (1995), "Psychological Contracts in Organizations: Understanding Written and Unwritten Agreements", Sage Publications, London.

Rousseau, D.M. and Wade-Benzoni, K.A., (1995), "Changing individualorganization attachments - a two way street", in Howard, A. (Ed.), San Francisco, CA.

Sammi, S., (1995), "Leasing your staff.", Association Management Vol. 47(Iss. 10): 7 pgs.

Sarker, S. J., Crossman, Alf, Chinmeteepituck, Parkpoom, (2003), "The relationships of age and tanure with job satisfaction: an examination of hotel meployees in Thailand", Journal of Managerial Psychology Vol. 18(Iss. 7/8): 14 pgs.

Segal, M. A., (2007), "Certain Tax Issues Concerning Employee Termination Fees", The CPA Journal Vol. 77(Iss. 7): 4 pages.

Shore, Ted H, (2004), "Equity sensitivity theory: do we all want more than we deserve?", Journal of Managerial Psychology; 2004; 19, 7; ABI/INFORM Global, pg. 722
Silvestro, R., (2002), "Dispelling the modern myth: Employee satisfaction and loyalty drive service profitability", International Journal of Operations \& Production Management. Vol. 22(Iss. 1): 20 pgs.

Spitzer, J John, (2006), "Delaying social security payments: a bootstrap", financial service review, Atlanta, vol 15 , Iss 3, p.14, 13 pgs

Sullivan, J. F., (2001), "Indirect compensation, the year a head" California management review.

Tauber, Y. D., Silverman, Carol S., (2002), "Employment contracts get employers in the game", Workspan Vol. 45(Iss. 8): 5 pgs.

Tytherleigh, M., C Webb, CL Cooper, C Ricketts, (2005), "Occupational stress in UK higher education institutions: A comparative study of all staff categories", Higher Education Research and Development Vol. 24(Iss. 1).

White, Lane, (2006), "The Challenges of Prosperity", Engineering and Mining Journal. New York: Oct 2006. Vol. 207, Iss. 8; pg. 26, 4 pgs

William, A., Perrewe, Pamela L, Kacmar, K. Michele, (1996), "Strategic Human Resources Management", Dryden press, Harcourt brace college publisher. 